\title{
WAKAF TUNAI SEBAGAI POTENSI PENGEMBANGAN EKONOMI DI INDONESIA \\ Sebuah Analisis antara Peluang dan Tantangan \\ Muhammad Djakfar
}

\begin{abstract}
Several instruments in Islam are prospectively developed to establish social awarness. Cash waqf, for instance, is a promising economic unit although it is considered alien in Is lamic community . In Indonesia, it is a potential source to increase the economic welfare. As a solution to economic cris is, cash waqf is a way to dig up financial source. Muslim may help the nation escape from economic turbulence as well as they show their obedience to God via charity. Different from the traditional concept of waqf which is dominantly associated to hectares of land, cash waqf does not necessarily need huge capital. It is only a sum of money which is allocated to an Islamic institution for communal development. Besides these opportunities, some problems are faced. People have not been well informed about the idea of cash waqf. This challenge should be solved by continuous socialization, particularly to waqif (waqf doer) candidate and nadzir (waqf organizer). Cash waqf arrangement is also important to raise welfare of society. Government with its political will has offered several alternatives to improve cash waqf, such as establishing waqf institution and opening waqf network.
\end{abstract}

Key words : Cash Waqf, Economic Development, Challenges and Opportunities

\section{Pendahuluan}

Sebagaimana diketahui bahwa Islam adalah agama filantrofistik alruistik yang mengedepankan keadilan sosial dan kesalehan sosial bagi semua (for all) sebagai implementasi dari watak dasar ajarannya, yaitu rahmatan lil 'alamin (Djakfar, 2005 : 46).

Di samping melindungi hak-hak individu (private) secara adil. Oleh karena itu Islam memberi kebebasan kepada pemeluknya untuk mengumpulkan harta kekayaan di atas prinsip bahwa sebagian dari harta itu adalah milik orang lain. Di dalam Islam tidak dikenal adanya kepemilikan mutlak (absolute), tetapi kepemilikan majazi (relative). Pemilik mutlak hanyalah Allah SWT, sedangkan manusia hanyalah sebatas pemilik sementara. Selaku pemegang amanah, bagaimanapun manusia harus mematuhi kehendak sang Pemilik Mutlak yang maksudnya agar harta itu sebagian disalurkan kepada pihakpihak yang berhak. Saluran kepada orang lain itu bisa melalui berbagai pintu, yaitu zakat, infak, sedekah, hibah, wasiat dan wakaf. Hal ini perlu dilakukan dengan tujuan untuk mengentas kemiskinan di kalangan umat Islam (lihat Qardhawi, 1397 H). 
Khusus bagian yang terakhir itu, yaitu wakaf, walaupun dalam kenyataan di Indonesia mempunyai potensi ekonomi yang sangat besar, namun sampai dewasa ini institusi keagamaan yang satu ini belum dieksplorasi secara optimal. Justru karena itu agar wakaf benar-benar bisa dikembangkan sebagai potensi pengembangan ekonomi umat di Indonesia, tentu saja perlu dikelola secara profesional oleh berbagai kalangan yang amanah, jujur dan mempunyai komitmen yang tinggi.

Objek wakaf, akhir-akhir ini tidaklah sebatas benda yang tak bergerak, seperti tanah, bangunan (sekolah, masjid, mushalla), pekuburan dan lain-lainnya. Termasuk pohon untuk diambil buahnya dan sumur untuk diambil airnya (Direktorat Pengembangan Zakat dan Haji, Dirjen Bimas Islam dan Penyelenggaraan Haji, 2004 : 1). Akan tetapi telah meluas pada harta yang bergerak, antara lain yang berupa uang, kendaraan, surat berharga, logam mulia, hak kekayaan intelektual (HAKI), dan lain-lain.

Menurut beberapa sumber bahwa wakaf tunai (uang) telah dipraktikkan oleh masyarakat yang menganut madzhab Hanafi (Dirjen Bimas Islam dan Penyelenggaraan Haji, 2004 : 1). Namun demikian perlu diakui bahwa pengembangan wakaf tunai akhirakhir ini tidak lepas dari jasa Prof. Dr. Muhammad Abdul Mannan, seorang ekonom Islam asal Bangladesh yang termasyhur di dunia. Dialah ketua pendiri Social Investment Bank Ltd (SIBL), Dhaka, Bangladesh, yang sangat antusias memaparkan konsep ekonomi Is lam yang berwatak kerakyatan di berbagai seminar tingkat dunia, yakni tentang wakaf tunai. Wakaf yang populer dalam Islam lebih banyak menekankan kepada benda yang tidak bergerak, maka sudah selayaknya dalam era modern ini dikembangkan kepada benda bergerak. Antara lain dalam bentuk wakaf tunai menuju sistem ekonomi Islam yang kontekstual, yang dalam pelaksanaannya, menurut Mannan, tetap menjamin keutuhan modal (mauquf) dan hasilnya digunakan untuk kesejahteraan sosial (mauquf 'alaih) (Tadjoedin, $2001: 4)$.

Bagaimanapun wakaf tunai merupakan bagian yang tidak terpisahkan dari sistem ekonomi Islam yang integral dan merupakan inovasi tunggal konsep Islam. Karena dalam masyarakat yang memiliki gaya hidup sekuler lebih mengandalkan pendekatan gaya hidup kaum kapitalisme yang melahirkan para borjuis, sudah barang tentu kita tidak menemukan sebuah konsep ekonomi yang murni sosial seperti dalam tatanan ideologi selain Islam (Fikri, $2001: 5)$. 
Wakaf tunai, kelak akan semakin dibutuhkan ketika umat Islam telah memiliki kesadaran yang tinggi akan manfaatnya. Karena sasaran operasionalnya yang dibidik adalah beberapa golongan (ashnaf) yang telah ditentukan dalam syariat Islam. Apalagi dari segi manfaat yang akan diraih bisa diprediksi tidak hanya akan dirasakan oleh umat Islam sendiri, melainkan seluruh umat manusia yang akan menikmati manfaat dari keberadaan instrumen ini.

Dalam konteks Indonesia dewasa ini yang ditandai dengan perkembangan sistem ekonomi Islam, kehadiran wakaf tunai hendaknya bukan sekedar wacana yang hanya didiskusikan saja, akan tetapi perlu ada pihak yang memprakarsai bagi lahir dan tumbuh kembangnya potensi ini. Diakui bahwa kondisi perekonomian Indonesia sejak pertengahan tahun 1997 dapat dikatakan belum pulih sebagaimana yang diharapkan. Bahkan kondisi terakhir dalam tahun 2005, dengan kenaikan harga bahan bakar minyak, beban ekonomi yang ditanggung rakyat Indonesia semakin berat. Indikatornya, antara lain ditandai dengan semakin banyaknya rakyat miskin (dhu'afa) dan termiskinkan (mustadh'afin), baik yang terselubung (laten) maupun yang kelihatan dipermukaan (manifest). Dalam kondisi objektif seperti inilah prakarsa mengeksplorasi potensi-potensi domistik sangatlah tepat sekali. Salah satunya adalah menggali potensi wakaf yang selama ini belum dilakukan secara optimal. Sekedar gambaran mengenai potensi wakaf tunai, jika sekiranya diasumsikan bahwa jumlah muslim kelas menengah di Indonesia sebesar 10 juta jiwa dengan penghasilan rata-rata per-bulan Rp.500.000 Rp.10.000.000,-, maka paling tidak akan terhimpun dana sekitar 3 (tiga) triliun pertahun. (lihat Direktorat Pengembangan Zakat dan Wakaf Dirjen Bimas Islam dan Penyelenggaraan Haji, 2004 : 25). Sebuah angka yang cukup fantastik yang bisa disumbangkan pada negara untuk segala keperluan pembangunan di Indonesia. Inilah sebuah peluang emas, sekaligus sebagai tantangan yang perlu dipikirkan dan ditindak lanjuti dengan melalui program yang matang dan berkesinambungan.

Namun demikian memanfaatkan wakaf tunai sebagai instrumen pengembangan ekonomi umat tidaklah semudah membalikkan telapak tangan. Oleh sebab itu di sinilah letak permasalahan yang akan didiskusikan dalam diskursus ini agar peluang dan tantangan itu benar-benar bisa dicarikan jalan keluarnya (way out) demi kemajuan 
ekonomi yang bisa dinikmati oleh umat Islam khususnya dan bangsa Indonesia pada umumnya.

\section{Pengertian, Sejarah dan Pendapat Ulama'}

Sebagaimana telah dikemukakan bahwa saat ini objek / harta wakaf tidak lagi terbatas pada benda tidak bergerak, akan tetapi berkembang ke arah benda yang bergerak. Perluasan pemahaman ini tentu saja sesuai dengan tuntutan realitas dan perkembangan berbagai macam harta yang secara syar'iy layak dijadikan objek wakaf sehingga bisa memberi kesempatan yang lebih banyak kepada calon wakif untuk berbuat baik kepada orang lain.

Di antara wakaf benda bergerak yang tergolong masih asing kedengarannya, namun akhir-akhir ini banyak diwacanakan berbagai kalangan adalah wakaf tunai yang dikenal dengan istilah cash waqf. Cash waqf diterjemahkan dengan wakaf tunai, namun kalau menilik objek wakafnya, yaitu uang, lebih tepat kiranya kalau cash waqf itu diterjemahkan dengan wakaf uang (Direktorat Pengembangan Zakat dan Wakaf Dirjen Bimas Islam dan Penyelenggaraan Haji, 2004 : 1). Wakaf tunai adalah wakaf yang bisa dilakukan oleh seseorang, kelompok orang, dan lembaga atau badan hokum dalam bentuk uang tunai. Termasuk ke dalam pengertian uang adalah surat-surat berharga, seperti saham, cek dan lainnya. Aspek hukum wakaf tunai telah menjadi perhatian para juris Islam (fuqaha'), akan tetapi dalam kenyataan wakaf uang itu telah dipraktikkan oleh masyarakat yang menganut madzhab Hanafi.

Terdapat silang pendapat mengenai hukum wakaf tunai. Iman al-Bukhari mengungkapkan bahwa menurut Imam az-Zuhri dinar dan dirham boleh diwakafkan, yaitu dengan cara menjadikannya sebagai modal usaha (dagang - tijarah), selanjutnya menyalurkan keuntungannya sebagai wakaf (Muhammad, 1997 : 20-21). Hal ini senada dengan pendapat Wahbah az-Zuhaili yang menyatakan bahwa madzhab Hanafi membolehkan wakaf tunai sebagai pengecualian, atas dasar Istihsan bi al'Urf, dengan alasan karena telah banyak dipraktikkan masyarakat. Madzhab Hanafi memang berpendapat bahwa hukum yang ditetapkan berdasarkan 'urf (adat kebiasaan) mempunyai kekuatan yang sama dengan hukum yang ditetapkan berdasarkan nash (teks) (lihat az- 
Zuhaili, 1985, juz VII : 162). Dasar yang dijadikan pijakan madzhab Hanafi, antara la in hadits yang diriwayatkan oleh Abdullah bin Mas'ud, ra. yang artinya : “ Apa yang dipandang baik oleh kaum muslimin, maka dalam pandangan Allah adalah baik, dan apa yang dipandang buruk oleh kaum muslimin maka dalam pandangan Allah pun buruk."

Adapun cara (kaifiyah) melalukan wakaf tunai (dalam bentuk uang) menurut madzhab Hanafi, ialah dengan menjadikannya sebagai modal usaha dengan cara mudharabah atau mubadha'ah, sedangkan keuntungannya disedekahkan untuk kemaslahatan umat (wakaf). Atau diinvestasikan dalam wujud saham di perusahaan yang bonafide atau didepositokan di perbankan syari'ah, dan keuntungannya dapat disalurkan sebagai hasil wakaf. Wakaf tunai yang diinvestasikan dalam wujud saham atau deposito, wujud atau lebih tepat nilai uangnya tetap terpelihara dan menghasilkan keuntungan dalam jangka waktu yang lama (Direktorat Pengembangan Zakat dan Wakaf Dirjen Bimas Islam dan Penyelenggaran Haji, 2004 : 4).

Berkaitan dengan sejarah wakaf tunai (disarikan dari Direktorat Pengembangan Zakat dan Wakaf Dirjen Bimas Islam dan Penyelenggaraan Haji, 2004, 9-13), pada masa dinasti Ayyubiyah di Mesir perkembangan wakaf sangat menggembirakan. Pada masa ini, wakaf tidak hanya sebatas pada benda tidak bergerak, tapi juga benda bergerak, semisal wakaf tunai. Dikatakan, tahun 1178 M / 572 M, dalam rangka mensejahterakan ulama dan kepentingan misi madzhab Sunni, Salahuddin al-Ayyuby menetapkan kebijakan bahwa orang Kristen yang datang dari Iskandar untuk berdagang wajib membayar bea cukai yang lazim dibayar dengan uang. Selanjutnya uang itu dikumpulkan dan diwakafkan kepada para fuqaha'dan para keturunannya.

Dinasti al-Ayyuby juga menjadikan harta milik negara yag berada di bait al-maal sebagai modal untuk diwakafkan demi pembangunan madzhab Sunni untuk menggantikan madzhab Syi'ah yang dibawa dinasti sebelumnya, yaitu dinasti Fathimiyah.

Dinasti Mamluk juga mengembangkan wakaf dengan pesatnya. Apa saja boleh diwakafkan dengan syarat dapat diambil manfaatnya. Tetapi yang banyak diwakafkan pada masa itu adalah tanah pertanian dan bangunan, seperti gedung perkantoran, penginapan dan tempat belajar. Juga, pada masa dinasti Mamluk terdapat hamba sahaya yang diwakafkan untuk merawat lembaga- lembaga agama. Misalnya mewakafkan budak 
untuk memelihara masjid dan madrasah. Hal ini dilakukan pertama kali oleh penguasa dinasti Usmani ketika menaklukkan Mesir, Sulaiman Basya yang mewakafkan budaknya untuk merawat masjid. Wakaf yang digunakan untuk lebih menyemarakkan syi'ar Islam adalah wakaf untuk sarana di Haramain, Mekkah dan Madinah seperti kain Ka'bah (kiswatul $\mathrm{ka}^{\prime} \mathrm{bah}$ ). Raja Shaleh bin al-Nasir, misalnya membeli desa Bisus lalu diwakafkan untuk membiayai kiswah Ka'bah setiap tahunnya dan mengganti kain kuburan Nabi saw dan mimbarnya setiap lima tahun sekali.

Dinasti Mamluk berpandangan bahwa wakaf telah menjadi tulang punggung dalam roda perekonomiannya, karena itu mereka memberi perhatian khusus terhadap wakaf. Bahkan mereka mengeluarkan kebijakan dengan mensahkan undang-undang wakaf. Undang-undang wakaf pada dinasti Mamluk dimulai sejak raja al-Dzahir Bibers al-Bandaq (1260-1277 M / 658 - 676 M), dimana dengan undang-undang tersebut raja alDzahir memilih hakim untuk mengurusi wakaf dari masing-masing empat madzhab Sunni. Pada masa ini perwakafan dibagi menjadi tiga kategori : pendapatan negara dari hasil wakaf yang diberikan oleh penguasa kepada orang-orang yang dianggap berjasa , wakaf yang membantu Haramain (fasilitas Mekkah dan Madinah) dan kepentingan masyarakat umum.

Penyebarluasan peraturan perwakafan semakin intensif dan semakin mudah dilakukan oleh kerajaan Turki Usmani. Hal ini terjadi karena kerajaan Turki Usmani mampu memperluas wilayah kekuasaannya, sehingga Turki dapat menguasai sebagian besar wilayah negara Arab. Di antara regulasi yang pernah dikeluarkan ialah peraturan tentang pembukuan pelaksanaan wakaf, yang dikeluarkan pada tanggal 19 Jumadil Akhir tahun $1280 \mathrm{H}$. Undang-undang tersebut mengatur tentang pencatatan wakaf, sertifikasi wakaf, cara pengelolaan wakaf, upaya mencapai tujuan wakaf dan melembagakan wakaf dalam upaya realisasi wak af dari sisi administratif dan perundang-undangan.

Selanjutnya tujuh tahun kemudian, $1287 \mathrm{H}$ juga dikeluarkan regulasi undangundang yang menjelaskan tentang kedudukan tanah-tanah kekuasaan Turki Usmani dan tanah-tanah produktif yang berstatus wakaf. Dengan regulasi itu implementasinya adalah di negara Arab masih banyak tanah yang berstatus wakaf yang dipraktikkan sampai saat ini. 
Sejalan dengan dinamika zaman, wakaf terus mendapat perhatian serius dan dilaksanakan di berbagai negara Islam, tanpa kecuali di Indonesia. Hal ini terbukti, bahwa institusi wakaf itu telah lama diterima menjadi hukum adat bangsa Indonesia sendiri. Sehingga di Indonesia terdapat banyak harta yang tersebar di berbagai daerah yang sebagian besar berpenduduk Muslim. Ke depan, kesungguhan mengeksplorasi dan mengembangkan potensi wakaf itu akan semakin kuat dengan lahirnya Undang-undang Republik Indonesia Nomor 41 Tahun 2004 tentang Wakaf yang bisa menjamin kepastian hukum berkaitan dengan pelaksanaan wakaf.

Diakui bahwa berkaitan dengan masalah wakaf tunai ini nampaknya masih terjadi silang pendapat (khilafiyah) di antara para fuqaha' (juris Islam) kendati sudah ada referensi yang bisa dijadikan sumber hukum yaitu dari al-Qur'an dan Hadits. Misalnya dalam surat Ali 'Imran, Allah SWT berfirman : 'Kamu sekali-kali tidak sampai kepada kebajikan (yang sempurna) sebelum kamu menafkahkan sebagian harta yang kamu cintai. Dan apa saja yang kamu nafkahkan maka sesungguhnya Allah mengetahui (QS. Ali 'Imran, 3 : 92). Dalam hadits Abu Hurairah r.a. yang sangat populer yang diriwayatkan oleh Imam Muslim, Nabi Muhammad saw bersabda : "Apabila anak Adam (manusia) meninggal dunia, maka putuslah amalnya, kecuali tiga perkara : sedekah jariyah, ilmu yang bermanfaat dan anak saleh yang mendoakan orang tuanya".

Ibn Abidin menyatakan bahwa wakaf tunai yang dikatakan merupakan kebiasaan ('urf) yang berlaku di kalangan masyarakat Romawi, di negeri lain wakaf tunai itu bukan merupakan kebiasaan. Karena itu ia berpandangan bahwa wakaf tunai tidak boleh atau tidak sah. Senada dengan pandangan ini adalah pendapat madzhab Syafi' i, yang menurut penjelasan al-Bakri yang menjadi sebab ('illat) ketidak bolehannya karena dirham dan dinar (baca : uang) akan lenyap ketika dibayarkan sehingga tidak ada lagi wujudnya (AlBakri, dalam Direktorat Pengembangan Zakat dan Wakaf Dirjen Bimas Islam dan Penyelenggaraan Haji, 2004 : 3). Akan tetap selain madzhab Hanafi, sebagian ulama madzhab Syafi'i juga membolehkan wakaf tunai. Abu Tsaur, misalnya meriwayatkan dari Imam Syafi' i tentang dibolehkannya wakaf dinar dan dirham (baca : uang) (Lihat AlMawardi, 1994 : 379).

Demikian juga Komisi Fatwa Majelis Ulama Indonesia (MUI) membolehklan praktik wakaf tunai, sebagaimana fatwa yang dikeluarkan pada tanggal 11 Mei 2002. 
Alasan hukumnya didasarkan kepada hadits Ibn Umar r.a. bahwa Umar bin Khathab r.a. ketika memperoleh tanah (kebun) di Khaibar, lalu ia datang kepada Nabi s.a.w untuk meminta petunjuk mengenai tanah tersebut. Ia berkata, 'Wahai Rasulullah, saya memperoleh tanah di Khaibar yang belum pernah saya peroleh harta yang lebih baik bagiku melebihi tanah tersebut. Apa perintah Engkau (padaku) tentang tanah itu? "Nabi s.a.w menjawab : “Jika mau, kamu tahan pokoknya dan kamu sedekahkan has ilnya”. Ibn Umar berkata ; "Maka Umar menyedekahkan tanah tersebut, dengan mensyaratkan tanah itu tidak dijual, tidak dihibahkan dan tidak diwariskan. Ia menyedekahkan hasilnya kepada fuqara', kerabat, riqab, sabilillah, ibnu sabil, dan tamu. Tidak berdosa atas orang yang mengelolanya untuk memakan dari (hasil) tanah itu secara ma'ruf (wajar) dan memberi makan (kepada orang lain) tanpa menjadikannya sebagai hak milik" (dalam Direktorat Pengembangan Zakat dan Wakaf Dirjen Bimas Islam dan Penyelenggaraan Haji, 2004 : 16).

Nampaknya, bertolak dari hadits itulah akhirnya MUI merumuskan definisi tentang wakaf, yaitu "menahan harta yang dapat dimanfaatkan tanpa lenyap bendanya atau pokoknya, dengan cara tidak melakukan tindakan hukum terhadap benda tersebut (menjual, memberikan, atau mewariskannya), untuk disalurkan (hasilnya) pada sesuatu yang mubah (tidak haram) yang ada" (Lihat Keputusan Komisi Fatwa MUI, tanggal 28 Shafar 1423 H / 11 Mei 2002 M).

\section{Wakaf Tunai : Peluang dan Tantangan}

Sub kajian ini ingin menjelaskan bahwasanya wakaf tunai mempunyai potensi yang sangat besar untuk mengembangkan ekonomi. Akan tetapi di tengah keterpurukan ekonomi bangsa Indonesia yang mayoritas Muslim ini potensi itu belum tergali sebagaimana yang diharapkan. Ini jelas merupakan peluang kepada siapapun yang secara sukarela mau menunaikannya. Namun demikian dibalik itu masih banyak tantangan yang mesti dihadapi dalam pelaksanaannya.

Memang perlu diakui bahwa selama ini, wakaf tunai yang berwujud uang itu masih menjadi harta idle karena belum banyak dieksplorasi dari para pemiliknya, terutama di kalangan si kaya (aghniya) sehingga belum bisa dimanfaatkan untuk keperluan kemaslahatan umat, terutama untuk pengembangan ekonomi. Hal ini bisa 
terjadi karena perbincangan tentang wakaf tunai baru mengemuka akhir-akhir ini seiring dengan berkembangnya sistem perekonomian dan pembangunan yang menghasilkan inovasi-inovasi baru.

Memang, apabila dibandingkan dengan masalah zakat, mendengar masalah wakaf rasanya masyarakat masih agak asing, apalagi menunaikannya. Terlebih lagi yang berkaitan dengan wakaf tunai kiranya akan semakin kurang dipahami karena selama ini yang lebih banyak didengar oleh mereka bahwa wakaf adalah sebatas yang berkaitan langsung dengan urusan masjid, madrasah dan kuburan. Dengan kata lain, nampaknya selama ini kesan yang muncul di kalangan masyarakat Muslim bahwa wakaf selalu identik dengan amal Islami yang tak terurus, tak terkelola, berjalan sendiri-sendiri, dan kurang bonafid. Padahal, di negara-negara lain, pengelolaan wakaf sudah sedemikian maju dan profesional (Nasution, $2001: 10$ ).

Kesan semacam itu adalah wajar, karena secara hukum, kedudukan institusi zakat wajib bagi setiap Muslim yang mampu sehingga implikasinya zakat harus ditunaikan terlebih dahulu daripada wakaf yang status hukumnya hanya sunnah (voluntary). Akan tetapi bisa diperkirakan bahwa hasil dari amal wakaf yang sifatnya sukarela itu benarbenar menakjubkan, asal saja dikelola secara serius dan profesional sebagaimana yang telah dipraktikkan di berbagai negara. Di Amerika Serikat misalnya, kendati negara sekuler, wakaf bagi warga Muslim minoritas di sana telah dikelola secara profesional oleh lembaga keuangan Islam yang sangat bonafid yaitu the Kuwait Awqaf Public Foundation (KAPF). Lembaga yang bermarkas di New York ini di bawah bimbingan lembaga advisor Al-Manzil Islamic Financial Services, yakni sebuah cabang bisnis keuangan dari the United Bank of Kuwait PLC, di mana Abdulkader Steven Thomas sebagai CEO-nya. Berkat upaya KAPF dan Al-Manzil tersebut, kini di New York telah berdiri sebuah proyek apartemen senilai US\$85 juta di atas tanah yang dimiliki the Islamic Cultural Center of New York (ICCNY).

Demikian pula di Bangladesh, Social Investment Bank Ltd. (SIBL) yang dikomandani oleh Prof. Dr. M.A. Mannan kini telah mengembangkan operasionalisasi Pasar Modal Sosial (the Voluntary Capital Market) melalui pengembangan instrumeninstrumen keuangan Islam seperti : Wagf Properties Development Bond, Cash Waqf Deposit Certificate, Family Waqf Certificate, Mosque Properties Development Bond, 
Mosque Community Share, Quard-e-Hasana Certificate, Zakat / Ushar Payment Certificate, Hjj Saving Certificate, Non-Muslim Trust Properties Development Bond, dan Municipal Properties Development Bond (Nasution, 2001 : 11).

Itu semua adalah sebagai bukti aktual betapa besar potensi wakaf yang bisa dikembangkan untuk menunjang kemajuan ekonomi dalam sebuah negara. Memang, dalam sejarah Islam tercatat bahwa keberadaan wakaf telah banyak membantu bagi pengembangan ilmu-ilmu pengetahuan, seperti medis melalui penyediaan fasilitasfasilitas publik di bidang kesehatan dan pendidikan. Pendidikan medis tidak hanya diberikan di sekolah-sekolah medis dan di rumah sakit, tetapi juga telah diberikan di masjid-masjid dan universitas- universitas seperti Universitas Al Azhar di Kairo-Mesir yang dibiayai dari hasil pengelolaan asset wakaf. Bahkan pada abad ke-4 Hijriyah, rumah sakit anak didirikan di Istambul (Turki) yang dananya berasal dari hasil pengelolaan aset wakaf. Dalam sejarah Islam, Turki diakatakan mempunyai sejarah terpanjang dalam pengelolaan wakaf yang mencapai kesuksesannya di zaman Utsmaniyah, di mana harta wakaf pada tahun 1925 diperkirakan mencapai 3/4 dari luas tanah produktif. Pada saat itu Pusat Administrasi Wakaf dibangun kembali setelah penggusurannya pada tahun 1924. Sekarang, di era modern, Waqf Bank \& Finance Corporation telah didirikan untuk memobilisasi sumber-sumber wakaf dan untuk membiayai bermacam-macam jenis proyek joint venture. Di Spanyol, fasilitas rumah sakit yang melayani baik Muslim maupun non Muslim, juga berasal dari pengelolaan aset wakaf. Dan pada periode Abbasiyah, dana hasil pengelolaan aset wakaf juga digunakan untuk membantu pembangunan pusat seni dan telah sangat berperan bagi perkembangan arsitektur Islam terutama arsitektur dalam pembangunan masjid, sekolah dan rumah sakit. Pada pertengahan abad ke-19, sekitar $1 / 2$ dari luas tanah produktif di Aljazair disumbangkan sebagai wakaf. Demikian juga di Tunisia pada tahun 1883, wakaf tanah di sana mencapai jumlah 1/3, di Turki pada tahun 1928 mencapai 3/4 , di Mesir pada tahun 1935 mencapai 1/7, Iran pada tahun 1930 mencapai 12\% (lihat Nasution, 2001 : 12-13). Di Indonesia, sebenarnya masyarakat bisa banyak belajar dari keberhasilan Badan Wakaf Pondok Modern Gontor Ponorogo, Universitas Islam Indonesia (UII) Yogyakarta dan Universitas Muslim Indonesia (UMI) Makassar (lihat Proyek Peningkatan Zakat dan Wakaf Dirjen Bimas Islam dan Penyelenggaraan Haji, 2003 : 23). Ketiganya merupakan contoh konkrit 
dan kelak akan tercacat dalam sejarah sebagai ikon keberhasilan lembaga pendidikan dalam mengelola aset wakaf sehingga bisa mengantar para mahasiswa - baik yang berasal dari dalam maupun mancanegara - ke jenjang pendidikan dari strata satu sampai strata tiga.

Lalu, bagaimana dengan kondisi di Indonesia, dan kemungkinan pengembangannya?. Dalam upaya memberi kesempatan yang luas bagi pelaksanaan perwakafan di Indonesia, Bank Indonesia mengemukakan definisi wakaf tunai, yaitu sebagai penyerahan aset wakaf berupa uang tunai yang tidak dapat dipindahtangankan dan dibekukan untuk selain kepentingan umum yang tidak mengurangi ataupun menghilangkan jumlah pokoknya (Tim Depag, 2003 : 24). Selanjutnya, kalau dicermati dalam kitab-kitab fikih, di antara persyaratan yang dibebankan kepada wakif tidak ditentukan bahwa harta yang dimiliki harus mencapai takaran tertentu, sehingga ia dapat mewakafkan sebagian hartanya. Karena itu dana wakaf, terutama wakaf tunai, dapat dihimpun tidak saja dari kelompok tertentu saja. Atau hanya terbatas dari golongan kaya (the have) sebagaimana dalam pemahaman paradigma lama. Akan tetapi saat ini konsep wakaf tunai memberi peluang yang seluas-luasnya kepada seluruh lapisan masyarakat yang secara sukarela hendak menyerahkan sebagian hartanya sebagai wakaf. Oleh karena itu perbankan Islam di Indonesia, sebenarnya, jika mereka lebih kreatif dan mampu memetakan potensi yang dimiliki umat Islam, tidak akan pernah kehabisan sumber likuiditas. Kalau Bangladesh dengan 120 juta jiwa, SIBL bisa eksis, kenapa Indonesia dengan 210 juta jiwa, perbankan Islam tidak eksis? (Nasution, 2001 : 15).

Karena itu untuk menangkap peluang itu perbankan syari'ah, terutama setelah keluarnya Undang-undang Republik Indonesia Nomor 41 Tahun 2004 tentang Wakaf, dapat menghimpun dana dari anggota masyarakat yang akan memberikan wakaf tunainya dengan menerbitkan Sertifikat Wakaf Tunai (lihat UU RI No. 41 Tahun 2004 tentang Wakaf). Penerbitan Sertifikat Wakaf Tunai akan memberi peluang penggalangan dana yang cukup besar karena, pertama, lingkup sasaran pemberi wakaf tunai (wakif) bisa menjadi sangat luas dibandingkan dengan wak af biasa. Kedua, Sertfifat Wakaf Tunai dapat dibuat dalam berbagai macam pecahan, yang disesuaikan dengan segmen Muslim yang dituju, yang kira-kira memiliki kesadaran yang tinggi untuk beramal. Misalnya, pecahan Rp. 10.000,-, Rp.25.000,-, Rp.50.000,-, Rp.100.000,- dan seterusnya (Direktorat 
Pengembangan Zakat dan Wakaf Dirjen Bimas Islam dan Penyelenggaraan Haji, 2004 : 24).

Diyakini, bahwasanya Muslim menengah Indonesia, sejatinya memiliki kesadaran yang cukup tinggi untuk beramal, sama halnya dengan gairah mereka untuk selalu menunaikan ibadah haji setiap tahun. Akan tetapi karena pintu beramal bagi mereka, di luar yang wajib, selama ini masih dikatakan terbatas, sehingga amal itu dialirkan ke sektor tradisional yang lazim di masyarakat, seperti untuk pembangunan masjid, pembangunan mushalla dan lain sebagainya. Oleh karena itu dengan adanya wakaf tunai niscaya merupakan ladang baru bagi masyarakat kelas menengah untuk banyak beramal. Pada bagian pendahuluan diskursus ini telah digambarkan secara sepintas, bagaimana potensi wakaf tunai di Indonesia. Akan tetapi pada bagian ini perlu dijelaskan kembali bagaimana kemungkinan potensi wakaf tunai yang bisa dikembangkan di Indonesia ke depan. Diasumsikan bahwa jumlah kelas menengah Muslim di Indonesia diperkirakan mencapai 10 juta jiwa dengan penghasilan rata-rata per-bulan berkisar antara Rp.500.000,- sampai Rp.10.000.000,- Jika nilai Sertifikat Wakaf Tunai dibagi ke dalam beberapa besaran nilai mulai Rp.5000,- hingga Rp.100.000,- misalnya, maka bisa diperkirakan paling tidak akan terkumpul dana sekitar 3 triliun per-tahun yang bisa disumbangkan untuk menunjang pembangunan di Indonesia. Selain itu, mobilisasi dana wakaf tunai yang jumlahnya cukup fantastik itu diharapkan bisa membantu pengembangan ekonomi dengan jaminan terlepas dari inefisiensi dalam penggunaannya. Namun demikian, bagaimanapun dana wakaf adalah dana amanah dari para wakif yang bernuansa spiritual sehingga penggunaannya harus memperhatikan koridor hukum syara'.

Peluang untuk menggalang dana melalui wakaf tunai tidak saja dari perorangan secara individual saja. Akan tetapi wakif secara kelembagaan - sekalipun belum dijelaskan secara panjang lebar di dalam kitab fikih - seperti dari Usaha Kecil dan Menengah serta Koperasi (UKMK) yang menurut Adi Sasono apabila UKMK tersebut diberdayakan akan mampu meningkatkan penerimaan yang dari pajak sebesar Rp.400 triliun. Selanjutnya apabila 2.5\% -nya dialihkan dalam bentuk wakaf tunai, maka akan terkumpul dana sebesar Rp.10 triliun, (lihat Mahmudi, dalam Direktorat Pengembangan Zakat dan Wakaf Dirjen Bimas Islam dan penyelenggaraan Haji, 2004 : 26). 
Dengan melihat betapa besar potensi wakaf tunai tersebut, maka pemberdayaan lembaga perwakafan yang merupakan salah satu instrumen finansial dalam sistem ekonomi Islam sudah waktunya untuk direalisasikan. Dan dana wakaf yang terkumpul tersebut hendaknya dimanfaatkan untuk kegiatan yang produktif agar supa ya manfaatnya dapat dirasakan oleh seluruh lapisan masyarakat. Dan pada akhirnya akan melahirkan kesejahteraan lahir dan batin (bandingkan dengan Qardhawi, 1397 H).

Adapun dana wakaf yang terkumpul tersebut merupakan dana abadi yang harus tetap ada yang akan terus memberi manfaat bagi masyarakat maupun wakif sampai akhir zaman. Akan tetapi untuk bisa merelisasik an gagasan itu tentunya membutuhkan program yang sistemik dan terorganisir yang didukung oleh sumber daya manusia yang profesional agar mampu mengatasi tantangan-tantangan yang menuntut pemecahan.

Munculnya gagasan wakaf tunai jelas menimbulkan tanda tanya karena berlawanan dengan persepsi umat Islam yang telah terbentuk bertahun-tahun lamanya. Diakomodirnya wakaf tunai dalam konsep wakaf sebenarnya merupakan hasil interpretasi radikal (ijtihad) yang mencoba mengubah definisi mengenai wakaf sesuai dengan perkembangan teori-teori ekonomi abad ini. Tampaknya, untuk merespons perubahan ini Majalis Ulama Indonesia (MUI) berupaya merumuskan definisi baru tentang wakaf sebagaimana telah dikemukakan sebelum ini. Karena hasil ijtihad baru inilah akan banyak ditemui tantangan yang harus dihadapi dalam pelaksanaannya. Antara lain yang paling pokok adalah bagaimana mengubah mindset agar masyarakat luas, terutama kelas menengah dan atas, mampu memahami peran strategis wakaf tunai yang bernilai ibadah dalam pembangunan ekonomi masyarakat, khususnya umat Islam. Caranya adalah perlu dilakukan sosialisasi. Untuk menyukseskan proses sosialisasi wakaf tunai ini Departemen Agama cq. Direktorat Pengembangan Zakat dan Wakaf telah menetapkan tiga strategi sosialisasi, yaitu sosialisasi konsep, pendekatan kepada calon wakif dan pendekatan kepada nadzir wakaf (lihat dalam Direk torat Pengembangan Zakat dan Wakaf Dirjen Bimas Islam dan Penyelenggaraan Haji, 2004 : 15 - 37).

Pertama, Sosialisasi Konsep. Saat ini regulasi yang menjamin operasionalisasi wakaf, termasuk wakaf tunai, semakin kuat dengan lahirnya Undang-undang Republik Indonesia Nomor 41 Tahun 2004 tentang Wakaf. Tugas pokok pemerintah saat ini adalah melakukan sosialisasi konsep agar dapat dipahami oleh masyarakat Muslim di Indonesia. 
Termasuk memperkenalkan bahwa di Indonesia sebenarnya sudah ada beberapa lembaga yang melaksanakan wakaf tunai yaitu, PB Matlaul Anwar dengan "Dana Firdaus", Dompet Dhuafa Republika dengan "Dompet Dhuafa”, Bank Muamalat Indonesia (BMI) dengan institusi barunya "Baitul Mal Mu'amalat". Kendati pelaksanaan pengelolaan wakaf tunai masih belum maksimal, sehingga belum dirasakan hasilnya oleh masyarakat banyak. Akan tetapi paling tidak upaya untuk memberdayakan wakaf tunai sudah mulai mengge liat dengan segala keterbatasannya.

Salah satu model yang dapat dikembangkan dalam mobilisasi wakaf tunai adalah model Dana Abadi, yaitu dana yang dihimpun dari berbagai sumber dengan berbagai cara yang sah dan halal, untuk selanjutnya dana yang terkumpul itu diinvestasikan dengan tingkat keamanan yang tinggi melalui lembaga penjamin syariah. Hanya saja dengan model Dana Abadi ini, konsep wakaf tunai masih perlu dilakukan beberapa penyesuaian yang diperlukan. Hal ini perlu dilakukan karena adanya persoalan yag melekat dalam model wakaf tunai, yaitu problem of perpetuity, persoalan keabadian selamanya. Karenanya, salah satu upaya preventif yang perlu dijelaskan kepada publik adalah dengan menegaskan tujuan wakaf tunai itu secara jelas. Termasuk, langkahlangkah yang harus ditempuh untuk mencapai tujuan yang meliputi instrumen, baik dari segi bentuk maupun nilainya.

Model Dana Abadi tersebut sangat layak dijadikan model untuk pengembangan wakaf tunai, karena beberapa alasan. Pertama, dapat membantu menjaga keutuhan aset tunai dari wakaf, sehingga dapat mengurangi perpetuitas yang melekat pada wakaf tunai; Kedua, dapat menjadi sumber pendanaan (source of financing) pada unit-unit usaha yang bersifat komersial maupun sosial, sehingga dapat mendorong aktifitas usaha secara lebih luas; dan yang ketiga, cakupan target wakaf menjadi lebih luas, terutama dari aspek mobilisasi maupun aspek alok asi dana wakaf.

Dalam aplikasinya, wakaf tunai dengan model Dana Abadi dapat diterbitkan Sertifikat Wakaf Tunai dengan nominasi atau nominal yang beragam disesuaikan dengan kemampuan sasaran yang akan dibidik. Disinilah keunggulan konsep wakaf tunai yang dapat menjangkau segmen masyarakat yang lebih variatif.

Selanjutnya yang perlu dijelaskan pula kepada publik adalah sepanjang yang menyangkut manfaat utama praktik wakaf tunai. Pertama, bahwa dengan dana 
terbataspun masyarakat bisa menunaikan wakaf, tanpa menunggu menjadi orang kaya terlebih dahulu; Kedua, aset-aset wakaf yang berupa tanah kosong bisa digali manfaatnya melalui pembangunan gedung atau diolah sebagai lahan pertanian yang produktif; Ketiga, bisa membantu sebagian lembaga lembaga pendidikan Islam yang cash flow-nya sangat terbatas untuk bisa digunakan membiayai segala aktivitas civitas akademika ala kadarnya; dan keempat, agar umat Islam lebih mandiri dalam mengembangkan dunia pendidikan, kesehatan, ekonomi dan lain sebagainya tanpa harus menggantungkan kepada dana pemerintah yang selama ini dapat dikatakan masih terbatas.

Yang perlu dipikirkan lagi di balik proses sosialisasi itu adalah bagaimana model dan mekanisme penerapan Sertifikat Wakaf Tunai ini dapat applicable dan feasible diterapkan di Indonesia dengan melibatkan berbagai infrastruktur yang sudah ada atau akan membangun infrastruktur baru dan menyesuaikannya dengan kultur masyarakat Indonesia sendiri.

Kedua, Pendekatan Kepada Calon Wakif. Untuk bisa menjaring harta wakaf benda-benda yang bergerak, khususnya wakaf tunai memang perlu pendekatan secara intens kepada calon wakif, terutama kepada mereka kelompok menengah dan atas (the have). Targetnya, agar mereka sadar dan merasa tergugah untuk menyisihkan sebagian kekayaannya untuk kepentingan sosial melalui wakaf tunai. Nampaknya yang dipakai oleh pemerintah untuk strategi sosialisasi pola kedua ini, antara lain adalah melalui pendekatan keagamaan, pendekatan kesejahteraan sosial, pendekatan bukti keberhasilan dan pendekatan efektifitas pemanfaatan hasil.

Pendekatan keagamaan dimaksudkan agar calon wakif merasa tersentuh bahwa wakaf tunai itu merupakan bagian dari ibadah yang berfungsi sebagai amal jariyah bagi siapapun yang menunaikannya. Karena itu dengan melihat kondisi riil sebagian besar masyarakat Muslim di Indonesia yang masih hidup di bawah garis kemiskinan, maka berarti turut menunaikan wakaf tunai merupakan peluang beramal yang sangat terpuji, sekaligus merupakan tantangan untuk ikut menyelesaikan problem sosial ekonomi mereka. Bukankah yang mampu mempunyai tanggung jawab sosial untuk mengentas kehidupan saudara-saudaranya yang kurang mampu. 
Selanjutnya dengan pendekatan bukti keberhasilan pengelolaan, perlu diyakinkan kepada calon wakif bahwa harta wakaf tunai yang telah dipraktikkan di Indonesia, misalnya oleh Dompet Dhuafa Republika, Bank Muamalah Indonesia dan lain-lainnya menunjukkan hasil yang sangat berarti. Kunci keberhasilan ini karena didukung oleh pelaksana (nadzir) yang amanah dan professional sehingga dengan demikian pada akhirnya akan mendorong pada aspek efektifitas dan efisiensi pemanfaatan hasil. Dalam arti, bahwa semua dana yang terhimpun akan dijamin tidak akan terjadi kebocoran karena semuanya akan diperuntukkan sesuai dengan tujuan wakaf tunai.

Ketiga, Pendekatan Kepada Nadzir Wakaf. Nadzir merupakan salah satu dari rukun wakaf yang menempati posisi yang sangat strategis dalam pengelolaan dana wakaf tunai. Oleh karena itu dengan posisinya itu, bagaimanapun nadzir sebagai pengelola harta wakaf harus memenuhi persyaratan tertentu, sebagaimana ditetapkan dalam fikih, antara lain muslim, mukallaf, 'aqil, baligh, amanah, jujur, dan adil. Tentu saja yang terakhir harus professional, terutama dalam menghadapi tantangan zaman ke depan.

Dengan melihat betapa strategis peran nadzir agar bisa melakukan tugas secara maksimal, maka seyogyanya para nadzir dimotivasi agar selalu meng-upgrade diri, terutama dalam kualifikasi pendidikan. Disinilah letak tantangan bagi setiap nadzir sebagai pemegang amanah, sekaligus tantangan bagi wakif untuk memilih nadzir yang berkualitas agar harta wakafnya bisa dikelola secara maksimal.

Yang perlu dipertanyakan saat ini. adalah sudah siapkah pemerintah melakukan proses sosialisasi wakaf tunai itu di seluruh Indonesia? Dengan telah diundangkannya Undang-undang Republik Indonesia Nomor 41 Tahun 2004 tentang Wakaf, tahun 2005 lalu telah dilakukan sebuah penelitian kendati dalam wilayah yang terbatas yaitu di kota Malang, Jawa Tmur. Penelitian ini ingin menggali, bagaimanakah tanggapan tokoh masyarakat terhadap pelaksanaan wakaf setelah diundangkannya undang-undang tersebut. Hasil penelitian antara menyimpulkan bahwa sementara ini kualitas sumber daya manusia (SDM) para nadzir masih belum memadai. Demikian pula yang berkaitan dengan proses sosialiasi belum bisa dilaksanakan secara maksimal karena keterbatasan dana pemerintah dan jumlah SDM sebagai tenaga pensosialisasi (lihat Djakfar : 2005). Apabila dikaitkan dengan program wakaf tunai yang akan digalakkan, kenyataan riil ini 
jelas perlu menjadi bahan pemikiran, sekaligus merupakan tantangan bagi pemerintah agar program itu bisa berhasil sesuai yang diharapkan.

\section{Strategi Pengembangan}

Ada beberapa strategi yang ditawarkan oleh Departemen Agama cq. Direktorat Pengembangan Zakat dan Wakaf berkaitan dengan strategi pengembangan wakaf tunai di Indonesia. Yaitu, pembentukan institusi wakaf, sistem pengelolaan dana wakaf, membuka jaringan dan kerjasama wakaf dan meningkatkan political will pemerintah. Khusus untuk strategi yang kedua, ditawarkan empat sistem alternatif pengelolaan dana wakaf, yairu memberi peran perbankan syariah, membentuk lembaga investasi dana, menjalin kemitraan usaha, atau memberi peran lembaga penjamin syariah (lihat Direktorat Pengembangan Zakat dan Wakaf Dirjen Bimas Islam dan Penyelenggaraan Haji, 2004 : 37 - 73).

Pertama, Pembentukan Institusi Wakaf. Dikatakan, bahwa untuk konteks Indonesia, lembaga wakaf yang secara khusus mengelola dana wakaf tunai dan beroperasi secara nasional adalah Badan Wakaf Indonesia (BWI). Hal ini sesuai dengan pasal 48 Undang-undang RI Nomor 41 Tahun 2004 yang menyatakan bahwa BWI berkedudukan di ibukota Negara Kesatuan Republik Indonesia dan dapat membentuk perwakilan di Provinsi dan / atau Kabupaten / Kota sesuai dengan kebutuhan. Selanjutnya dalam pasal 49 ayat (1) ditegaskan bahwa tugas dan wewenang BWI adalah a). melakukan pembinaan terhadap nadzir dalam mengelola dan mengembangkan harta benda wakaf, dan b). mengembangkan harta benda wakaf berskala nasional dan internasional. Demikian seterusnya masih banyak tugas yang lain lagi. Dalam melaksanakan tugasnya (pasal 49, ayat 2), BWI dapat bekerjasama dengan instansi pemerintah baik pusat maupun daerah, organisasi masyarakat, para ahli, badan internasional, dan pihak lain yang dipandang perlu. Dan dalam melaksanakan tugas sebagaimana dalam pasal 49, BWI memperhatikan saran dan pertimbangan Menteri dan Majelis Ulama Indonesia (pasal 50).

Untuk bisa menjalankan tugas dan wewenangnya, BWI harus dikelola oleh sumber daya manusia (SDM) yang benar-benar mempunyai kemampuan dan kemauan 
dalam mengelola wakaf, berdedikasi tinggi dan memiliki komitmen dalam pengembangan wakaf. Dengan kata lain agar lembaga ini berhasil mengemban misinya, bagaimanapun harus didukung oleh SDM yang mempunyai integritas moral, sosial dan pendidikan yang memadai dalam berbagai disiplin keilmuan.

Kedua, Sistem Pengelolaan Dana Wakaf. Agar dana wakaf tunai bisa dikelola secara professional, tentu diperlukan pola / sistem yang bisa diterapkan. Pertama, sistem tersebut terkait dengan pemberian peran kepada perbankan syariah yang meliputi berbagai kemungkinan alternatif, yaitu bank syariah sebagai nadzir penerima, penyalur dan pengelola wakaf. Selanjutnya alternatif kedua, bank syariah hanya sebagai nadzir penerima dan penyalur dana wakaf, sedangkan fungsi pengelola dana dilakukan oleh lembaga lain, misalnya BWI. Alternatif ketiga, bank syariah terbatas sebagai pengelola (fund manager) dana wakaf. Adapun alternatif yang keempat, bank syariah hanya berfungsi sebagai kustodi. Sedangkan alternatif kelima hanya sebagai kasir BWI saja.

Di samping memberi peran kepada lembaga perbankan syariah, alternatif lain yang bisa ditempuh adalah membentuk lembaga investasi dana. Hanya saja jenis investasi yang harus digalang dan dilakukan adalah pada instrumen keuangan yang sesuai dengan syariat Islam dan tidak mengandung unsur riba. Selain itu untuk mendukung keberhasilan pengembangan aspek produktif dari dana wakaf tunai, masih bisa ditempuh ke arah sektor usaha yang produktif dengan lembaga usaha yang memiliki reputasi yang baik dan bonafid. Salah sati caranya adalah dengan melakukan kerjasama (networking) dengan perusahaan moral ventura.

Sebagai sebuah konsep yang relatif baru dalam Islam, pengelolaan wakaf tunai harus betul-betul amanah dan aman (savety) karena terkait dengan keabadian benda wakaf yang tidak boleh berkurang. Di samping juga sebagai jaminan kepercayaan kepada publik selaku wakif. Persoalan yang muncul adalah bagaimana jalan keluarnya jika sekiranya dalam pengeloaannya kelak mengalami kerugian (lost)?. Jika pengelolaan wakaf tunai diserahkan kepada bank syariah melalui konsep Wadiah, di mana bank syariah yang mencari perusahaan untuk investasi, karena banklah yang lebih mengetahui mana perusahaan yang layak dan dana wakaf tidak akan hilang karena dijamin oleh bank syariah tersebut. Namun, apabila dana wakaf tunai dikelola oleh lembaga nadzir independen dengan pola pengembangan melalui sistem perusahaan, maka resiko kerugian 
akan sangat mungkin terjadi. Karena itu, untuk menjamin keamanan dana itu maka diperlukan lembaga penjamin syariah. Hanya saja lembaga penjamin syariah disini harus jelas kontrak atau akad yang dipakai. Karena praktik kontrak akan menentukan / mempengaruhi sah atau tidaknya secara syariah.

Demikian pula dengan kontrak antara peserta dengan perusahaan asuransi. Kalau asuransi konvensional menerapkan kontrak yang disebut kontrak jual beli (tabaduli) yang tidak jelas berapa besarnya premi yang harus dibayarkan karena tergantung terhadap kondisi usaha peserta. Cara semacam ini dalam praktiknya mengundang cacat hukum. Lain halnya apabila asuransi syariah sebagai penjamin karena kontrak yang akan digunakan bukan kontrak jual beli, melainkan kontrak tolong menolong (takafuli). Dalam hal ini asuransi syariah mengeterapkan apa yang disebut sebagai kontrak tabarru' yang dapat diartikan sebagai derma atau sumbangan. Tujuan tabarru' ini adalah untuk memberikan dana kebajikan dengan ikhlas untuk saling membantu sesama peserta asuransi syariah apabila di antara mereka ada yang terkena musibah. Oleh karenanya dana tabarru' disimpan dalam satu rekening khusus, di mana jika terjadi risiko, dana klaim yang diberikan adalah dari rekening dana tabarru' yang sudah dianggarkan untuk saling menolong sesama peserta. Akhirnya dengan melihat praktik antar lembaga penjamin itu, maka lembaga yang tepat dan sesuai dengan prinsip syariah adalan asuransi syariah.

Ketiga, Membuka Jaringan dan Kerjasama Wakaf. Upaya lain yang tidak kalah strategisnya untuk mengembangkan dana wakaf tunai adalah membuka jaringan (networking) dan kerjasama wakaf, baik di bidang kelembagaan maupun kepakaran. Baik dalam skala nasional maupun internasional. Hal ini perlu dilakukan dalam rangka meningkatkan kajian-kajian yang bersifat konseptual maupun teknik pengelolaan dan pengembangan wakaf. Dari kerjamasama inilah diharapkan adanya sharing pengalaman (experience) dan masukan dari berbagai pakar sesuai disiplin keilmuannya masingmasing yang semuanya itu masih dalam bingkai untuk mendukung kemajuan pengelolaan wakaf tunai di masa depan. Dan dari sinilah diharapkan munculnya ide inovasi-inovasi baru dalam pemberdayaan potensi ekonomi wakaf secara lebih mensejahterakan.

Jika sekiranya jaringan kepakaran itu benar-benar telah terjalin, maka untuk memfollow up-i lebih jauh niscaya perlu dibentuk jaringan secara lebih spesifik seperti 
jaringan permodalan, investasi dan pengembangan. Di Indonesia, yang sangat memungkinkan untuk dijadikan ujung tombak permodalan dan investasi adalah perbankan syariah, sertifikat wakaf tunai dan lain-lainnya. Sedangkan di tingkat internasional, berbagai upaya pengembangan permodalan dan investasi dan pengembangan wakaf sudah dilakukan negara-negara anggota OKI yang diprakarsai oleh IDB yang berpusat di Jeddah. Seperti pengembangan wakaf yang dilakukan oleh sebuah divisi yang disebut Islamic Economic Cooperation and Development Division (IECD).

Di samping itu untuk mengatasi sebagian problem yang dihadapi oleh berbagai lembaga wakaf di Indonesia yaitu di seputar kurangnya informasi tentang sumbersumber, kerjasama maupun teknik pengembangan wakaf secara umum, perlu dibentuk jaringan informasi dan komunikasi. Secara teknis, hal ini dapat dilakukan oleh net providers Muslim yang sekarang sedang berkembang dengan pesat. Seperti yang telah dilakukan di beberapa negara Islam, antara lain Mesir, Oman, Qatar, Syria dan Kuwait. Negara-negara ini telah mengembangkan situs-situs Website yang dapat diakses.

Hal lain yang tidak kalah krusialnya dalam upaya mensosialisasikan projek pengembangan wakaf tunai, sekarang sudah saatnya didirikan media cetak dan multi media yang secara khusus mengembangkan informasi tentang wakaf tunai. Media bisa berupa Jurnal atau Majalah tentang wakaf agar informasi di dalamnya bisa diakses para akademisi dan praktisi (nadzir) sehingga mereka akan semakin kaya imajinasi, kreasi dan inovasi baru yang bisa dikembangkan di masa yang akan datang di tempat masingmasing.

Keempat, Meningkatkan Political Will Pemerintah. Setelah berhasil mengundangkan regulasi tentang wakaf pada tahun 2004 yang lalu sebenarnya tugas pemerintah ke depan semakin berat. Keberadaan undang-undang tidak akan bermakna tanpa adanya tindak lanjut ke arah pencapaian tujuan yang diidealkan. Karena itu perwujudan political will pemerintah hendaknya banyak diarahkan pada upaya mengkaji ulang berbagai aspek yang berkaitan dengan masalah perwakafan dengan memetakan apa yang mendukung dan apa yang menghambat. Upaya sosialisasi dan ketersediaan sumber daya manusia yang selama ini masih dirasa belum memadai adalah merupakan salah satu aspek yang perlu mendapat perhatian. Di samping aspek-aspek lain yang belum banyak dipetakan demi 
perbaikan sistem pengelolaan wakaf yang pada gilirannya apa yang diharapkan dari konsep wakaf tunai benar-benar akan banyak membantu untuk pengembangan ekonomi di Indonesia.

\section{Kesimpulan}

Bertolak dari uraian di atas dapat dipahami bahwa konsep wakaf tunai sebagai hasil ijtihad baru dari pemahaman lama tentang wakaf sudah saatnya ditangani secara sungguh-sungguh, terprogram, berkesinambungan dan profesional. Secara teoritis, betapa fantastik jumlah dana yang bisa dikumpulkan melalui ibadah sosial yang voluntary ini jika bisa diwujudkan secara maksimal. Dalam konteks Indonesia yang sekarang sedang mengalami keterpurukan ekonomi yang dirasa semakin berat ditanggung oleh seluruh strata masyarakat, merealisasikan program wakaf tunai merupakan sebuah peluang bagi para calon wakif untuk membantu mereka yang berkekurangan secara ekonomi.

Akan tetapi bersamaan dengan peluang itu masih terdapat sejumlah tantangan yang harus dihadapi yang apabila tidak direspons secara bijak akan mengurangi nilai peluang yang bisa dilakukan. Karena regulasi tentang wakaf yang selama ini dipersoalkan telah resmi diundangkan, tantangan pertama dan utama yang perlu digalakkan adalah proses sosialisasi konsep dengan objek sasarannya kepada para calon wakif dan nadzir wakaf.

Sebagai follow up hasil sosialisasi yang sudah diterima dan dipahami oleh masyarakat, selanjutnya perlu dikuti dengan strategi pengembangan ke depan, antara lain dengan membangun institusi wakaf yang representatif sesuai dengan prinsip syariah. Di samping perlu ada pemikiran bagaimana cara pengelolaan dana yang telah dihimpun agar tetap aman pokoknya dan bisa dimanfaatkan hasilnya. Tentu saja, strategi pengembangan itu akan semakin kuat jika sekiranya didukung oleh pihak eksternal dalam bentuk jaringan dan kerjasama wakaf. Tanpa mengenyampingkan peran pokok pemerintah agar selalu konsisten pada pengembangan wakaf tunai di Indonesia dengan jalan memfasilitasi segala instrumen yang dibutuhkan. 


\section{Daftar Pustaka}

Al-Bakri, I'anat al-Thalibin, Kairo : Isa al-Halabi, tt

Al-Mawardi, al-Hawi al-Kabir, Beirut : Daar al-Fikr, Juz IX, 1994

Al-Qur'an al-Karim

Az-Zuhaili, Wahbah, al-Fiqh al-Islami wa Adillatuhu, Damsyk : Daar al-Fikr, Juz VII, 1985

Djakfar, Muhammad, "Peran Strategis Wakaf Sebagai Pilar Pengembangan Ekonomi Umat : Sebuah Tawaran Solusi Dalam Konteks Indonesia ke Depan”, dalam Iqtishoduna, Jurnal Ekonomi \& Bisnis Islam Fakultas Ekonomi UIN Malang, edisi Juli 2005

--------, Prospek Wakaf Sebagai Potensi Pengembangan Ekonomi Umat Setelah Diundangkannya Undang-undang Republik Indonesia Nomor 41 Tahun 2004 tentang Wakaf : Studi Pandangan Tokoh Masyarakat di Kecamatan Lowokwaru Kota Malang, Departemen Agama Universitas Islam Negeri (UIN) Malang, 2005

Fikri, H. Ali, "Kata Pengantar”, dalam M.A. Mannan, Sertifikat Wakaf Tunai : Sebuah Inovasi Instrumen Keuangan Islam, ed. Mustafa E. Nasution, Jakarta : CIBER bekerjasama dengan PKTTI-UI, 2001

Keputusan Komisi Fatwa Majelis Ulama Indonesia (MUI) tentang Wakaf Uang, 28 Shafar 1423 H / 11 Mei 2002

Mahmudi, "Mempertegas Pembangunan Ekonomi Kerakyatan", Harian Umum Republika, Nopember 2001, dalam Pedoman Pengelolaan Wakaf Tunai, Direktorat Pengembangan Zakat dan Wakaf Direktorat Jenderal Bimbingan Masyarakat Islam dan Penyelenggaraan Haji, 2004

Muhammad, Abu As-Su'ud, "Risalatu fi Jawazi Waqfi an-Nuqud," Beirut : Daar Ibn Hazm, 1997, dalam Pedoman Pengelolaan Wakaf Tunai, Direktorat Pengembangan Zakat dan Wakaf Direktorat Jenderal Bimbingan Masyarakat Islam dan Urusan Haji, 2004

Nasution, Mustafa Edwin, "Prakata Editor", dalam M.A. Mannan, Sertifikat Wakaf Tunai ; Sebuah Inovasi Instrumen Keuangan Islam, ed. Mustafa E. Nasution, Jakarta : CIBER bekerjasama dengan PK TTI-UI, 2001

Pedoman Pengelolaan wakaf Tunai, Direktorat Pengembangan Zakat dan Wakaf, Direktorat Jenderal Bimbingan Masyarakat Islam dan Penyelenggaraan Haji, 2004 
Qardhawi, Yusuf, Musykilah al-Faqr wa Kaifa Alajaha al-Islam, Kairo - Mesir : Maktabah Wahbah, 1397 H / 1977 M

Strategi Pengembangan Wakaf Tunai di Indonesia, Direktorat Pengembangan Zakat dan Wakaf Direktorat Jenderal Bimbingan Masyarakat Islam dan Penyelenggaraan Haji, 2004

Tadjoedin, Achmad Ramzy, "Pangantar", dalam M.A. Mannan, Sertifikat Wakaf Tunai : Sebuah Inovasi Instrumen Keuangan Islam, ed. Mustafa E. Nasution, Jakarta : CIBER bekerjasama dengan PK TTI-UI, 2001

Tim Departemen Agama, Fiqih Wakaf, Jakarta : Depaetemen Agama RI, 2003

Undang-undang Republik Indonesia Nomor 41 Tahun 2004 tentang Wakaf 